\title{
PENGARUH BOKASHI DAN PUPUK NPK TERHADAP PERTUMBUHAN DAN HASIL KACANG PANJANG
}

\section{THE EFFECT OF BOKASHI AND NPK FERTILIZER ON THE GROWTH AND YIELD OF LONG BEAN}

\author{
Ahmad Raksun* dan Lalu Japa \\ Program Studi Pendidikan Biologi, Jurusan Pendidikan MIPA, FKIP Universitas Mataram. \\ Jalan Majapahit No 62 Mataram, 83125, Indonesia \\ *Email: ahmadunram@unram.ac.id
}

Diterima: 1 Agustus 2019. Disetujui: 1 Agustus 2019. Dipublikasikan: 31 Juli 2019

\begin{abstract}
Abstrak. Pemupukan tanaman dapat dilakukan dengan menggunakan pupuk sintetik dan pupuk organik. Penelitian tentang pengaruh pupuk organik bokashi dan pupuk sintetik NPK terhadap pertumbuhan dan hasil kacang panjang, telah dilaksanakan di Desa Sukarara Kabupaten Lombok Tengah. Tujuan dilaksanakannya penelitian ini adalah untuk mengetahui: (1) pengaruh bokashi terhadap pertumbuhan dan hasil kacang panjang, (2) pengaruh pupuk NPK terhadap pertumbuhan dan hasil kacang panjang, (3) pengaruh interaksi bokashi dan pupuk NPK terhadap pertumbuhan dan hasil kacang panjang. Dalam penelitian ini digunakan rancangan faktorial yang terdiri dari 2 faktor. Faktor pertama adalah dosis bokashi dan faktor kedua adalah dosis pupuk NPK. Data penelitian dianalisis dengan analisis sidik ragam. Hasil penelitian menunjukkan bahwa (1) pemberian bokashi berpengaruh nyata terhadap pertumbuhan dan hasil kacang panjang, (2) pemberian pupuk NPK berpengaruh nyata terhadap pertumbuhan dan hasil kacang panjang, (3) interaksi bokashi dan pupuk NPK berpengaruh nyata terhadap pertumbuhan dan hasil kacang panjang.
\end{abstract}

Kata kunci: bokashi, pupuk NPK, pertumbuhan dan hasil kacang pajang

Abstract. Fertilizing plants can be done using synthetic fertilizers and organic fertilizers. Research on the effect of bokashi and NPK fertilizer on the growth and yield of long beans has been carried out in Sukarara Village, Central Lombok. The purpose of this research is to find out: (1) the influence of bokashi on the growth and yield of long beans, (2) the effect of NPK fertilizer on the growth and yield of long beans, (3) the effect of interaction between bokashi and NPK fertilizer on growth and yield of long beans. In this research a factorial design consisting of 2 factors ware used. The first factor is the bokashi dose and the second factor is the dose of NPK fertilizer. Data were analized by using Anova. The results showed that (1) bokashi has a significant effect on the growth and yield of long beans, (2) NPK fertilizer significantly affected the growth and yield of long beans, (3) the interaction of bokashi and NPK fertilizer significantly affected the growth and yield of long beans.

Keywords: bokashi, NPK fertlizer, growth and yield of long bean

\section{PENDAHULUAN}

Kacang panjang merupakan tanaman sayuran yang banyak dibudidayakan oleh masyarakat Pulau Lombok. Buah kacang panjang dapat dihidangkan mentah sebagai lalapan atau diolah menjadi berbagai macam masakan. [2] menjelaskan bahwa kacang panjang merupakan sumber protein dan karbohidrat yang berguna untuk memenuhi gizi. Kacang panjang yang umumnya dipanen dalam bentuk polong muda banyak mengandung vitamin $\mathrm{A}$ sedangkan polong tua banyak mengandung protein dan karbohidrat
Pemupukan merupakan salah satu upaya yang dapat dilakukan untuk meningkatkan pertumbuhan dan hasil panen tanaman budidaya termasuk kacang panjang. Pemupukan dapat dilakukan dengan menggunkakan pupuk organik dan pupuk sintetik. Salah satu pupuk organik yang dapat dimanfaatkan untuk memacu pertumbuhan dan hasil panen kacang panjang adalah bokashi. Selanjutnya pupuk sintetik yang dapat digunakan adalah pupuk NPK

Hasil penelitian yang sudah dilakukan menunjukkan bahwa pemberian bokashi pada lahan pertanian dapat meningkatkan pertumbuhan dan produksi jagung. Kadar optimum bokashi yang perlu diberikan pada lahan pertanian agar tanaman jagu 
dapat tumbuh dan berproduksi secara optimal adalah $0,8 \mathrm{~kg}$ per $10 \mathrm{~kg}$ tanah [9]. Pemberian bokashi berpengaruh signifikan terhadap produksi cabai rawit. Kadar optimum bokashi yang perlu diberikan pada lahan pertanian agar cabai rawit berproduksi secara optimal adalah $1,0 \mathrm{~kg}$ untuk setiap $10 \mathrm{~kg}$ tanah [10]. Penggunaan bokashi EM4 memberikan pengaruh terhadap penambahan tinggi tanaman umur 3 dan 4 minggu setelah tanam dan jumlah daun tanaman sawi umur 2, 3 dan 4 minggu setelah tanam serta produksi (berat basah) tanaman sawi. Penggunaan bokashi EM 4 dapat meningkatkan efisiensi pemakaian pupuk kimia. Pemberian dosis kombinasi pupuk kimia (NPK 75\%) dengan penambahan bokashi EM 4 merupakan pilihan terbaik untuk diterapkan oleh petani sawi [13]

Selanjutnya penggunaan pupuk NPK juga berpengaruh signifikan terhadap pertumbuhan tanaman. Pemberian pupuk NPK 142 g (100\% dari dosis rekomendasi) meningkatkan panjang pelepah bibit pada umur 9 bulan, bobot kering tajuk dan bobot kering akar bibit kelapa sawit di main nursery. Terdapat interaksi antara pupuk NPK dan pupuk organik terhadap bobot kering akar bibit kelapa sawit di main nursery. Interaksi terbaik terdapat pada perlakuan pemberian pupuk NPK 50\% dan pupuk organik $36 \mathrm{~g}$ polibeg $^{-1}$ [1].

Berdasarkan uraian di atas maka peneliti melakukan penelitian tentang pengaruh bokashi dan pupuk NPK terhadap pertumbuhan dan hasil kacang panjang yang dilakukan di Desa Sukarara Kecamatan Jonggat Kabupaten Lombok Tengah. Adapun tujuan dilaksanakannya penelitian ini adalah untuk mengetahui: (1) pengaruh bokashi terhadap pertumbuhan dan hasil kacang panjang, (2) pengaruh pupuk NPK terhadap pertumbuhan dan hasil kacang panjang, (3) pengaruh interaksi bokashi dan pupuk NPK terhadap pertumbuhan dan hasil kacang panjang

\section{BAHAN DAN METODE}

Bahan-bahan yang digunakan adalah benih kacang panjang, bokashi, pupuk NPK, mulsa plastik, kertas transparan, bambu, air, insektisida dan fungisida. Selanjutnya alat-alat yang digunakan adalah parang, cangkul, ember plastik, timbangan, alat tulis menulis, gunting, artco dorong dan hand sprayer. Penelitian ini telah dilaksanakan pada bulan Mei sampai dengan Nopember 2018. Percobaan lapangan dilaksanakan di lahan pertanian Desa Sukarara Kabupaten Tengah.

Rancangan percobaan yang digunakan adalah Rancangan factorial dengan 3 ulangan. Faktor pertama adalah dosis bokashi yang terdiri atas 4 level, yaitu: tampa bokashi $\left(\mathrm{B}_{0}\right)$, perlakuan $0,6 \mathrm{~kg}$ bokashi per $1 \mathrm{~m}^{2}$ lahan $\left(\mathrm{B}_{1}\right)$, perlakuan $1.2 \mathrm{~kg}$ bokashi per $1 \mathrm{~m}^{2}$ lahan $\left(\mathrm{B}_{2}\right)$, perlakuan $1,8 \mathrm{~kg}$ bokashi per $1 \mathrm{~m}^{2}$ lahan $\left(\mathrm{B}_{3}\right)$. Faktor kedua adalah dosis pupuk NPK yang terdiri atas 4 level. yaitu: $K_{0}=$ tampa pemberian pupuk NPK (kontrol), $\mathrm{K}_{1}=$ pemberian 5 g pupuk NPK/tanaman, $K_{2}=$ pemberian 10 gr pupuk NPK/tanaman, $\quad \mathrm{K}_{3}=$ pemberian $15 \mathrm{~g}$ pupuk NPK/tanaman. Parameter pertumbuhan yang diukur adalah panjang daun, lebar daun dan panjang batang. Selanjutnya parameter produksi yang diukur adalah berat basah buah kacang panjang. Data kuantitatif hasil pengukuran parameter pertumbuhan dan produksi kacang panjang dianalisis dengan analisis sidik ragam [4]

\section{HASIL PENELITIAN DAN PEMBAHASAN}

Data hasil pengukuran panjang batang kacang panjang pada tabel 1 menunjukkan bahwa panjang batang kacang panjang terendah adalah $46 \mathrm{~cm}$ terdapat pada perlakuan $\mathrm{P}_{0} \mathrm{~K}_{0}$ (perlakuan $0 \mathrm{~kg}$ bokashi dan 0 gr pupuk NPK). Panjang batang kacang panjang tertinggi adalah $74 \mathrm{~cm}$ terdapat pada perlakuan $\mathrm{P}_{2} \mathrm{~K}_{3}$ (perlakuan $1,2 \mathrm{~kg}$ bokashi dan $15 \mathrm{gr}$ pupuk NPK). Selanjutnya hasil analisis sidik ragam pengaruh perlakuan bokashi dan pupuk NPK terhadap panjang batang kacang panjang menunjukkan bahwa pemberian bokashi berpengaruh sangat nyata terhadap panjang batang kacang panjang. Perlakuan pupuk NPK berpengaruh sangat nyata terhadap panjang batang kacang panjang. Interaksi bokashi dan pupuk NPK berpengaruh sangat nyata terhadap panjang batang kacang panjang.

Hasil pengukuran panjang daun kacang panjang tabel 2 menunjukkan bahwa panjang daun kacang panjang tertinggi adalah $114 \mathrm{~mm}$ terdapat pada perlakuan $\mathrm{P}_{2} \mathrm{~K}_{3}$ (perlakuan $1,2 \mathrm{~kg}$ bokashi dan $15 \mathrm{gr}$ pupuk NPK). Panjang daun kacang panjang terendah adalah $95 \mathrm{~mm}$ terdapat pada perlakuan $\mathrm{P}_{0} \mathrm{~K}_{0}$ (perlakuan $0 \mathrm{~kg}$ pupuk bokashi dan 0 gr pupuk NPK). Hasil analisis data menunjukkan bahwa aplikasi bokashi berpengaruh sangat nyata terhadap panjang daun kacang panjang. Perlakuan pupuk NPK berpengaruh sangat nyata terhadap panjang daun kacang panjang. Interaksi bokashi dan pupuk NPK berpengaruh sangat nyata terhadap panjang daun kacang panjang.

Data hasil pengukuran lebar daun kacang panjang pada tabel 3 menunjukkan bahwa lebar daun kacang panjang terendah adalah $95 \mathrm{~mm}$ terdapat pada perlakuan $\mathrm{P}_{0} \mathrm{~K}_{0}$ (perlakuan $0 \mathrm{~kg}$ pupuk bokashi dan 0 gr pupuk NPK). Selanjutnya lebar daun kacang panjang tertinggi adalah $70 \mathrm{~mm}$ terdapat pada perlakuan $\mathrm{P}_{2} \mathrm{~K}_{3}$ (perlakuan $1,2 \mathrm{~kg}$ pupuk bokashi dan 
15 gr pupuk NPK). Hasil analisis data menunjukkan bahwa pemberian bokashi berpengaruh nyata terhadap lebar daun kacang panjang. Perlakuan pupuk NPK berpengaruh nyata terhadap lebar daun kacang panjang. Interaksi pupuk bokashi dan pupuk NPK berpengaruh sangat nyata terhadap lebar daun kacang panjang.

Hasil pengukuran berat basah buah kacang panjang pada tal 4 menunjukkan bahwa berat basah buah kacang panjang terendah adalah $511 \mathrm{gr}$ terdapat pada perlakuan $\mathrm{P}_{0} \mathrm{~K}_{0}$ (perlakuan $0 \mathrm{~kg}$ pupuk bokashi dan 0 gr pupuk NPK). Berat basah buah kacang panjang tertinggi adalah 620 gr terdapat pada perlakuan $\mathrm{P}_{2} \mathrm{~K}_{3}$ (perlakuan $1,2 \mathrm{~kg}$ pupuk bokashi dan 15 gram pupuk NPK). Hasil analisis sidik ragam menunjukkan bahwa pemberian bokashi berpengaruh sangat nyata terhadap berat basah kacang panjang. Perlakuan pupuk NPK berpengaruh sangat nyata terhadap berat basah buah kacang panjang. Interaksi bokashi dan pupuk NPK berpengaruh sangat nyata terhadap berat basah buah kacang panjang.

Hasil penelitian menunjukkan bahwa pemberian bokashi pada media tanam berpengaruh sangat nyata terhadap panjang batang, panjang daun dan lebar daun dan berpengaruh nyata terhadap berat basah buah kacang panjang. Adanya pengaruh tersebut diduga disebabkan karena bokashi yang ditambahkan pada media tanam dapat meningkatkan kesuburan tanah dan pertumbuhan tanaman. Penelitian yang dilakukan oleh [6] pada tanaman jagung manis menunjukkan bahwa pemberian berbagai jenis bokashi memberikan pengaruh yang sangat nyata terhadap pertumbuhan dan hasil jagung manis, pemberian bokashi daun Johar memberikan hasil yang lebih baik terhadap pertumbuhan jagung manis, sedangkan pemberian bokashi daun Gamal memberikan hasil yang lebih baik terhadap produksi jagung manis

Hasil penelitian ini sejalan dengan hasil penelitian lainnya. Pemberian bokashi ampas biji kakao memberikan pengaruh terhadap tinggi tanaman, jumlah daun, luas daun, bobot segar tajuk dan bobot segar akar pada tanaman petsai. Bokashi $100 \%$ ampas biji kakao dan bokashi $75 \%$ ampas biji kakao yang ditambahkan dengan $25 \%$ pupuk kandang sapi dan sekam padi mampu memberikan hasil tertinggi pada tanaman petsai [12]. Selanjutnya [5] melaporkan bahwa pemupukan bokashi dengan dosis 20 ton per hektar memberikan bobot gabah kering per hektar tertinggi $(4,70$ ton), jumlah anakan produktif tertinggi $(25,00)$ dicapai varietas cianjur. [9] yang melakukan penelitian pada tanaman tomat melaporkan bahwa pertumbuhan dan produksi tanaman tomat terbaik terdapat pada perlakuan interaksi antara varietas Betavila dan dosis pupuk bokashi kotoran ayam 15 ton per ha. Perlakuan dosis pupuk bokashi kotoran ayam 15 ton/ha adalah yang paling baik untuk pertumbuhan dan hasil tanaman tomat

Pemberian pupuk NPK juga berpengaruh positip terhadap pertumbuhan dan hasil kacang panjang. Sejumlah penelitian lain menunjukkan hasil yang sejalan dengan penelitian ini. Penelitian yang dilakukan oleh [3] menunjukkan bahwa perlakuan pupuk NPK mutiara dapat mempercepat pertumbuhan tanaman gaharu yang ditanam pada lahan terbuka di tanah ultisol. Hasil analisis ragam menunjukan adanya pengaruh yang sangat nyata pemberian pupuk NPK mutiara terhadap pertumbuhan tanaman gaharu. Pemberian pupuk NPK mutiara 100 gram per tanaman mempunyai pertambahan tinggi yang lebih cepat. [7] melaporkan bahwa penerapan teknologi pemupukan dapat meningkatkan produksi bawang merah sebesar 64,69 gram per rumpun diperoleh pada pemberian pupuk N $250 \mathrm{~kg}$ per hektar dan K $100 \mathrm{~kg}$ per hektar. Pemberian dosis pupuk N $250 \mathrm{~kg}$ per hektar dan K $100 \mathrm{~kg}$ per hektar memberikan pengaruh yang sangat nyata terhadap peningkatan produksi bawang merah. Hasil produksi tersebut sejalan dengan parameter pertumbuhan seperti jumlah anakan per tanaman, jumlah umbi dan bobot umbi basah.

Selanjutnya penelitian yang dilakukan oleh [8] pada tanaman jagung menunjukkan bahwa perlakuan bahan organik 20 ton per hektar yang disertai dengan pupuk NPK dengan dosis urea $200 \mathrm{~kg}$ per kektar, SP-36 $200 \mathrm{~kg}$ per hektar dan $\mathrm{KCl} 100 \mathrm{~kg}$ per hektar menghasilkan jumlah daun jagung (42 hari setelah tanam), bobot basah tongkol dan klobot, bobot kering biji jagung lebih tinggi dari pada perlakuan lainnya. Produksi jagung tertinggi yaitu 7,83 ton per hektar terdapat pada perlakuan bahan organik 20 ton per hektar yang disertai dengan pupuk NPK dengan dosis urea $200 \mathrm{~kg}$ per kektar, SP-36 200 $\mathrm{kg}$ per hektar dan $\mathrm{KCl} 100 \mathrm{~kg}$ per hektar dan terendah yaitu 5,16 tor per hektar terdapat pada perlakuan bahan organik 20 ton per hektar yang disertai dengan pupuk NPK dengan dosis urea $100 \mathrm{~kg}$ per kektar, SP$36100 \mathrm{~kg}$ per hektar dan $\mathrm{KCl} 50 \mathrm{~kg}$ per hektar. [11] melaporkan bahwa aplikasi pupuk NPK berpengaruh sangat nyata terhadap pertumbuhan. vegetatif melon Interaksi pupuk organik dan pupuk NPK tidak berpengaruh nyata terhadap pertumbuhan vegetatif melon. Dosis optimum pupuk NPK adalah 15 gram per tanaman. 
J. Pijar MIPA, Vol. 14 No.2, 2019: 73 - 83

ISSN 1907-1744 (Cetak)

DOI: $10.29303 /$ jpm.v14i2.1181

ISSN 2410-1500 (Online)

Tabel 1. Rerata panjang batang kacang panjang akibat perlakuan bokashi dan pupuk NPK umur 25 hari setelah

\begin{tabular}{lcrc} 
tanam & & & \\
\hline Perlakuan & Panjang batang $(\mathrm{cm})$ & $\mathrm{P}_{2} \mathrm{~K}_{0}$ & Panjang batang $(\mathrm{cm})$ \\
\hline $\mathrm{P}_{0} \mathrm{~K}_{0}$ & 46 & $\mathrm{P}_{2} \mathrm{~K}_{1}$ & 61 \\
$\mathrm{P}_{0} \mathrm{~K}_{1}$ & 49 & $\mathrm{P}_{2} \mathrm{~K}_{2}$ & 63 \\
$\mathrm{P}_{0} \mathrm{~K}_{2}$ & 52 & $\mathrm{P}_{2} \mathrm{~K}_{3}$ & 70 \\
$\mathrm{P}_{0} \mathrm{~K}_{3}$ & 54 & $\mathrm{P}_{3} \mathrm{~K}_{0}$ & 74 \\
$\mathrm{P}_{1} \mathrm{~K}_{0}$ & 55 & $\mathrm{P}_{3} \mathrm{~K}_{1}$ & 60 \\
$\mathrm{P}_{1} \mathrm{~K}_{1}$ & 58 & $\mathrm{P}_{3} \mathrm{~K}_{2}$ & 60 \\
$\mathrm{P}_{1} \mathrm{~K}_{2}$ & 60 & $\mathrm{P}_{3} \mathrm{~K}_{3}$ & 65 \\
$\mathrm{P}_{1} \mathrm{~K}_{3}$ & 63 & & 67 \\
\hline
\end{tabular}

Tabel 2. Rerata panjang daun kacang panjang akibat perlakuan bokashi dan pupuk NPK umur 25 hari setelah tanam

\begin{tabular}{lccc}
\hline Perlakuan & Panjang daun $(\mathrm{mm})$ & Perlakuan & Panjang daun $(\mathrm{mm})$ \\
\hline $\mathrm{P}_{0} \mathrm{~K}_{0}$ & 95 & $\mathrm{P}_{2} \mathrm{~K}_{0}$ & 106 \\
$\mathrm{P}_{0} \mathrm{~K}_{1}$ & 97 & $\mathrm{P}_{2} \mathrm{~K}_{1}$ & 109 \\
$\mathrm{P}_{0} \mathrm{~K}_{2}$ & 97 & $\mathrm{P}_{2} \mathrm{~K}_{2}$ & 110 \\
$\mathrm{P}_{0} \mathrm{~K}_{3}$ & 99 & $\mathrm{P}_{2} \mathrm{~K}_{3}$ & 114 \\
$\mathrm{P}_{1} \mathrm{~K}_{0}$ & 99 & $\mathrm{P}_{3} \mathrm{~K}_{0}$ & 102 \\
$\mathrm{P}_{1} \mathrm{~K}_{1}$ & 98 & $\mathrm{P}_{3} \mathrm{~K}_{1}$ & 103 \\
$\mathrm{P}_{1} \mathrm{~K}_{2}$ & 99 & $\mathrm{P}_{3} \mathrm{~K}_{2}$ & 106 \\
$\mathrm{P}_{1} \mathrm{~K}_{3}$ & 103 & $\mathrm{P}_{3} \mathrm{~K}_{3}$ & 109 \\
\hline
\end{tabular}

Tabel 3. Hasil Analisis Sidik Ragam Pengaruh Perlakuan Bokashi dan Pupuk NPK terhadap lebar daun kacang panjang

\begin{tabular}{lcccccc}
\hline Sumber Keragaman & & & & & \multicolumn{2}{c}{ F tabel } \\
\hline & DB & JK & KT & F. Hitung & $5 \%$ & $1 \%$ \\
\hline Ulangan & 2 & 84,53 & 42,265 & & & \\
Perlakuan & 15 & 1234,61 & 82,307 & & & \\
Pupuk Organik (A) & 3 & 213,24 & 71,08 & $3,07^{*}$ & 2,92 & 4,51 \\
Pupuk NPK (B) & 3 & 285,45 & 95,15 & $4,11^{*}$ & 2,92 & 4,51 \\
A x B & 9 & 735,92 & 81,769 & $3,53^{* *}$ & 2,21 & 3,06 \\
Galat & 30 & 695,2 & 23,173 & & & \\
Umum & 47 & 2014,34 & 42,858 & & & \\
\hline
\end{tabular}

Tabel 4. Rerata berat basah buah kacang panjang akibat perlakuan bokashi dan pupuk NPK

\begin{tabular}{lccc}
\hline Perlakuan & Berat Buah (gram) & Perlakuan & Berat Buah (gram) \\
\hline $\mathrm{P}_{0} \mathrm{~K}_{0}$ & 511 & $\mathrm{P}_{2} \mathrm{~K}_{0}$ & 592 \\
$\mathrm{P}_{0} \mathrm{~K}_{1}$ & 523 & $\mathrm{P}_{2} \mathrm{~K}_{1}$ & 606 \\
$\mathrm{P}_{0} \mathrm{~K}_{2}$ & 536 & $\mathrm{P}_{2} \mathrm{~K}_{2}$ & 612 \\
$\mathrm{P}_{0} \mathrm{~K}_{3}$ & 554 & $\mathrm{P}_{2} \mathrm{~K}_{3}$ & 620 \\
$\mathrm{P}_{1} \mathrm{~K}_{0}$ & 564 & $\mathrm{P}_{3} \mathrm{~K}_{0}$ & 583 \\
$\mathrm{P}_{1} \mathrm{~K}_{1}$ & 572 & $\mathrm{P}_{3} \mathrm{~K}_{1}$ & 592 \\
$\mathrm{P}_{1} \mathrm{~K}_{2}$ & 586 & $\mathrm{P}_{3} \mathrm{~K}_{2}$ & 604 \\
$\mathrm{P}_{1} \mathrm{~K}_{3}$ & 694 & $\mathrm{P}_{3} \mathrm{~K}_{3}$ & 610 \\
\hline
\end{tabular}

\section{KESIMPULAN}

Dalam penelitian dapat disimpulkan bahwa: (1) perlakuan bokashi berpengaruh nyata terhadap pertumbuhan dan hasil kacang panjang, (2) perlakuan pupuk NPK berpengaruh nyata terhadap pertumbuhan dan hasil kacang panjang, (3) interaksi bokashi dan pupuk NPK berpengaruh nyata 
terhadap pertumbuhan dan hasil kacang panjang, (4) dosis optimum bokashi untuk tanaman kacang panjang adalah $1,2 \mathrm{~kg}$ bokashi per $1 \mathrm{~m}^{2}$ lahan, (5) dosis optimum pupuk NPK untuk tanaman kacang panjang adalah 15 gram per tanaman.

\section{DAFTAR PUSTAKA}

[1] Adnan, I.S., B. Utoyo dan A. Kusumastuti. 2015. Pengaruh Pupuk NPK dan Pupuk Organik terhadap Pertumbuhan Bibit Kelapa Sawit (Elaeis guineensis Jacq.) di Main Nursery. Agro Industri Perkebunan Vol. 3 (2): $69-81$

[2] Cahyono, B. 2005. Kacang Panjang (Teknik Budidaya dan Analisis Usaha tani) CV Aneka Ilmu. Semarang.

[3] Fiolita, V., A. Muin dan Fahrizal. 2017. Penggunaan Pupuk NPK Mutiara untuk Peningkatan Pertumbuhan Tanaman Gaharu (Aquilaria sp.) pada lahan Terbuka di Tanah Utisol. Hutan Lestari. Vol. 5 (3): 850 - 857

[4] Gomez K.A. dan A.A. Gomez. 1995. Prosedur Statistik Untuk penelitian Pertanian Edisi Kedua Penerjemah: Endang Syamsudin dan Justika S. Baharsyah. UI Press. Jakarta.

[5] Mulyana, D., Sahidin dan Iqbal, A. 2011. Pengaruh Dosis Bokashi terhadap Pertumbuhan dan Hasil Tiga Varietas Padi. Agrin Vol 15(1) p. 18 - 2

[6] Mulyanti, S.S., Made, U. dan Wahyudi, I. Pengaruh Pemberian Berbagai Jenis Bokashi terhadap Pertumbuhan dan Hasil Jagung Manis (Zea mays Saccarata). Agrotekbis Vol 3(5) p. $592-601$

[7] Napitupulu, D dan L. Wiharto. 2010. Pengaruh Pemberian Pupuk N dan K
Terhadap Pertumbuhan dan Produksi Bawang merah. J. Hort. Vol. 20 (1): 27 - 35

[8] Rahman, I.A., S. Djuniwati dan K. Idris. 2008. Pengruh Bahan Organik dan Pupuk NPK terhadap Serapan Hara dan Produksi Jagung di Inceptisol Ternate. Tanah dan Lingkungan. Vol. 10 (1): 7 - 13

[9] Raksun, A. 2008. Pengaruh Pemberian Bokashi Terhadap Pertumbuhan dan Produksi Jagung. Pijar MIPA Vol 3 (1): 6 - 10

[10] Raksun, A. dan I.G. Mertha. 2017. Pengaruh Bokashi terhadap Produksi Cabai Rawit. Biologi Tropis. Vol. 17 (2): 45 - 70

[11] Raksun, A., L. Japa dan I.G. Mertha. 2019. Aplikasi Pupuk Organik dan NPK untuk Meningkatkan Pertumbuhan Vegetatif Melon(Cucumis melo L.) Biologi Tropis Vol. 19 (1): $19-24$

[12] Riry, N., H. Rehatta dan V. L. Tanasale. 2013. Pengaruh Berbagai Komposisi Bokashi Ampas Biji Kakao dan Pemberian EM4 yang Berbeda terhadap Pertumbuhan dan Produksi tanaman Petsai (Brassica chinensis L.). Agrologia. Vol. 2 (2): 132 146.

[13] Ryan, I. 2010. Respon Tanaman Sawi (Brasica juncea.L.) Akibat Pemberian Pupuk NPK dan Penambahan Bokashi pada Tanah Asal Bumi Wonorejo Nabire. Agroforestri Vol 5 (4): $310-320$

[14] Sahetapy, M.M., J. Pongoh dan W. Tilaar, 2017. Analisis Pengaruh Beberapa Dosis Pupuk Bokashi Kotoran Ayam terhadap Pertumbuhan dan Produksi Tiga Varietas Tomat (Solanum lycopersicum L). di Desa Airmadidi. Agri-SosioEkonomi Unsrat. Vol. 13 (2): $70-82$ 